CAKRAWALA - Repositori IMWI | Volume 3, Nomor 2, Oktober 2020

p-ISSN: 2620-8490; e-ISSN: 2620-8814

\title{
KEPEMILIKAN INSTITUSIONAL DAN KOMPENSASI BONUS SERTA PENGARUHNYA TERHADAP MANAJEMEN LABA PADA PERUSAHAAN ASURANSI YANG TERDAFTAR DI BURSA EFEK INDONESIA TAHUN 2017-2019
}

\author{
Novi Susyani \\ Universitas Jenderal Achmad Yani, Bandung, Jawa Barat Indonesia \\ novi.susyani855@lecture.unjani.ac.id \\ Santi Maria \\ STIA Bagasasi, Bandung, Jawa Barat Indonesia \\ santimaria1010@gmail.com \\ Cucu Hodijah \\ Institut Manajemen Wiyata Indonesia, Sukabumi, Jawa Barat Indonesia \\ Cucu_hodijah@imwi.ac.id
}

\begin{abstract}
This study aims to determine the effect of institutional ownership and bonus compensation both simultaneously and partially on earnings management in insurance sector issuers on the Indonesia Stock Exchange (BEI) 2017-2019. The type of research used is verification research or hypothesis testing research. By using the census method and unbalanced panel data, there were 68 observation companies that met the population criteria. The type of data used is secondary data obtained from the capital market reference center on the Indonesia Stock Exchange. Multiple regression analysis model is used to test the hypothesis. The results of this study indicate that (1) Institutional ownership has a negative effect on earnings management. (2) bonus compensation has a negative effect on earnings management, and (3) Institutional ownership and bonus compensation simultaneously have an effect on earnings management.
\end{abstract}

Keywords: Institutional Ownership, Bonus Compensation And Earnings Management

\section{PENDAHULUAN}

Laporan keuangan merupakan salah satu sumber informasi yang wajib dipublikasikan sebagai sarana pertanggungjawaban pihak manajemen terhadap pengelolaan sumber daya pemilik. Salah satu informasi yang terdapat di dalam laporan keuangan adalah informasi laba. Statement of Financial Accounting Concept (SFAC) No. 1, menyebutkan bahwa informasi laba pada umumnya merupakan perhatian utama dari laporan keuangan dalam mengetahui kinerja manajemen. Informasi laba sebagai bagian dari laporan keuangan sering menajdi target rekayasa melalui tindakan oportunis manajemen untuk kepuasannya. Tindakan oportunis tersebut dilakukan dengan cara memilih kebijakan akuntansi tertentu, sehingga laba perusahaan dapat diatur sesuai dengan keinginannya. Perilaku tersebut dikenal dengan manajemen laba.

Dilihat dari nilai perusahaan akan tercermin dari harga pasar sahamnya (Fama, 1978). (Jensen \& Meckling, 1976) menjelaskan bahwa untuk memaksimumkan nilai perusahaan tidak hanya nilai ekuitas saja yang harus diperhatikan, tetapi juga semua klaim keuangan seperti hutang, warran maupun saham preferen. Penyatuan kepentingan pemegang saham, debtholders, dan 
manajemen yang merupakan pihak-pihak yang mempunyai kepentingan terhadap tujuan perusahaan seringkali menimbulkan masalah-masalah keagenan (agency problem). Agency problem yaitu permasalahan yang terjadi akibat hubungan antara pemilik perusahaan dengan pengelola perusahaan. Sujoko dan Subiantoro (2007) menemukan bahwa kepemilikan institusional mempunyai pengaruh negatif dan signifikan terhadap nilai perusahaan.

Melihat dari hasil-hasil penelitian sebelumnya menemukan beberapa faktor yang diduga berpengaruh terhadap manajemen laba. (Jensen \& Meckling, 1976) menemukan bahwa perilaku manipulasi oleh manajer berawal dari konflik kepentingan yang dapat diminimumkan melalui suatu mekanisme monitoring yang bertujuan untuk menyelaraskan (alignment) berbagai kepentingan, yaitu dengan memperbesar kepemilikan saham oleh manajemen (managerial ownership), sehingga kepentingan pemilik atas pemegang saham akan dapat disejajarkan dengan kepemilikan manajer.

(Palestin, 2009) menyatakan bahwa dengan menggunakan mekanisme bonus dalam teori keagenan, kepemilikan manajemen di bawah 5\% terdapat keinginan dari manajer untuk melakukan manajemen laba agar mendapatkan bonus yang besar. Kepemilikan manajemen di atas $25 \%$, karena manajemen mempunyai kepemilikan yang cukup besar dengan hak pengendalian perusahaan, maka asimetri informasi menjadi berkurang.

Objek penelitian yang digunakan adalah perusahaan asuransi yang terdaftar di BEI karena perusahaan asuransi merupakan perusahaan yang mempunyai karakteristik berbeda dengan perusahaan pada umumnya, perusahaan asuransi mengambil alih resiko dari pihak lain sehingga perusahaan asuransi lebih padat resiko dari pada perusahaan lain. Nasabah perusahaan asuransi banyak dari masyarakat umum yang menggantungkan uangnya agar dikelola oleh perusahaan asuransi, sehingga ketika perusahaan tidak dikelola dengan baik oleh manajemen akan banyak orang yang menjadi korban.

Berdasarkan latar belakang tersebut, maka peneliti mengangkat judul penelitian ini "Kepemilikan Institusional Dan Kompensasi Bonus Serta Pengaruhnya Terhadap Manajemen Laba Pada Perusahaan Asuransi Yang Terdaftar Di Bursa Efek Indonesia Tahun 20172019".

\section{a. Tujuan Dan Manfaat Penelitian}

Tujuan penelitian ini adalah untuk menguji Kepemilikan Instutisional dan Kompensasi Bonus terhadap Manajemen Laba pada Perusahaan Asuransi yang terdaftar di Bursa Efek Indonesia Tahun 2017-2019”.

1. Apakah Kepemilikan Institusional dan kompensasi bonus berpengaruh terhadap manajemen laba pada Perusahaan Asuransi yang terdaftar di Bursa Efek Indonesia Tahun 20172019.

2. Apakah Kepemilikan Instutisional terhadap manajemen laba pada Perusahaan Asuransi yang terdaftar di Bursa Efek Indonesia Tahun 20172019.

3. Apakah Kompensasi Bonus berpengaruh terhadap Manajemen Laba pada Perusahaan Asuransi yang terdaftar di Bursa Efek Indonesia Tahun 2017-2019.

\section{b. Manfaat Penelitian}

1. Bagi peneliti, dapat menambah, memperluas wawasan dan 
mengembangkan ilmu pengetahuan khususnya bagi riset-riset keuangan sebagai pertimbangan untuk melakukan penelitian selanjutnya mengenai faktorfaktor yang mempengaruhi manajemen laba.

2. Bagi Perusahaan studi ini dapat digunakan untuk pertimbangan pengambilan keputusan sehingga dapat menghindari terjadinya praktek manajemen laba yang dapat merugikan

3. Bagi investor dapat digunakan sebagai pertimbangan dalam menyertakan modal nya diperusahaan dengan kualitas manajemen yang baik.

\section{TINJAUAN PUSTAKA}

\section{a. Kepemilikan Institusional}

Menurut (Bernandhi \& Muid, 2013), kepemilikan institusional adalah kepemilikan saham suatu perusahaan oleh institusi atau lembaga seperti perusahaan asuransi, bank, perusahaan investasi dan kepemilikan institusi lainnya. kepemilikan institusional memiliki peranan yang sangat penting dalam meminimalisasi konflik keagenan yang terjadi antara manajer dan pemegang saham. Keberadaan investor institusional dianggap mampu menjadi mekanisme monitoring yang efektif dalam setiap keputusan yang diambil oleh manajer.

(Lin \& Fu, 2017) menyatakan bahwa investor institusional yang aktif melakukan monitoring terhadap bisnis perusahaan, dapat mengurangi asimetri informasi dan problem keagenan sehingga dapat meningkatkan kinerja perusahaan. Investor institusional dapat menerapkan kemampuan manajerial, pengetahuan profesional dan hak suara mereka untuk mempengaruhi manajer dalam meningkatkan efisiensi perusahaan. Investor institusional juga dapat membantu perusahaan dalam membuat keputusan bisnis. Ketika perusahaan membutuhkan tambahan dana, investor institusional dapat menyediakan dana tambahan atau menggunakan jaringan mereka untuk membantu perusahaan dalam memperoleh sumber pendanaan.

\section{b. Kompensasi Bonus}

Bonus plan hypothesis merupakan salah satu motif pemilihan suatu metode akuntansi tidak terlepas dari positif accounting theory. Hipotesis ini menyatakan bahwa manajer perusahaan dengan rencana bonus lebih menyukai metode akuntansi yang meningkatkan laba periode berjalan. Pilihan tersebut diharapkan dapat meningkatkan nilai sekarang bonus yang akan diterima seandainya komite kompensasi dari Dewan Direktur tidak menyesuaikan dengan metode yang dipilih (Ghozali, 2005). Jika perusahaan memiliki kompensasi (bonus scheme), maka manager akan cenderung melakukan tindakan yang mengatur laba bersih untuk dapat mekasimalkan bonus yang mereka terima. Dalam kontrak bonus dikenal dua istilah penting yaitu bogey dan cap

\section{Manajemen Laba}

Manajemen laba menurut (Schipper, 1989 dalam Rahmawati dkk, 2006), merupakan suatu intervensi dengan memiliki tujuan dan maksud tertentu dalam proses penyusunan laporan keuangan eksternal untuk memperoleh keuntungankeuntungan pribadi bagi pihak tertentu.

Manajemen laba juga diartikan oleh (Healy dan Wallen, 1999 dalam Priantinah, 2008) sebagai penyusunan transaksi laporan keuangan dengan mengubah laporan keuangan menggunakan judgement sehingga dapat menyesatkan stakeholder 
dalam melihat kinerja ekonomi perusahaan.

Manajemen laba mempunyai definisi yang beragam dan belum ada penjelasan yang jelas mengenai batasan dan definisi manajemen laba (Sulistyanto, 2008). Maka berdasarkan dengan defenisi yang beragam diatas dapat disimpulkan bahwa manajemen laba merupakan suatu perilaku manajer dalam mengolah laba yang dilaporkan dalam laporan keuangan dengan tujuan untuk menguntungkan pihak-pihak tertentu.

\section{Kerangka Pemikiran}

\section{Hubungan Kepemilikan Institusional dengan Manajemen Laba}

Tindakan pengawasan tersebut dapat mendorong manajer untuk lebih memfokuskan perhatiannya terhadap kinerja perusahaan, sehingga akan mengurangi perilaku opportunistic atau mementingkan diri sendiri. Moh'd et al. (1998) dalam Midiastuty dan Mahfoedz (2003) menyatakan bahwa investor institusional merupakan pihak yang dapat memonitor agen dengan kepemilikannya yang besar, sehingga motivasi manajer untuk mengatur laba menjadi berkurang. Persentase saham tertentu yang dimiliki oleh institusi dapat mempengaruhi proses penyusunan laporan keuangan yang tidak menutup kemungkinan terdapat akrualisasi sesuai kepentingan pihak manajemen. Penelitian Midiastuty dan Mahfoedz (2003) menemukan hubungan negatif antara kepemilikan institusional terhadap manajemen laba.

\section{Hubungan Kompensasi Bonus dengan Manajemen Laba}

Penelitian yang dilakukan (Palestin, 2009) menunjukkan adanya hubungan positif antara kompensasi bonus dengan manajemen laba. Dengan ini dapat disimpulkan bahwa jika perusahaan memiliki kompensasi (bonus scheme), maka manajer akan cenderung melakukan tindakan yang mengatur laba bersih untuk dapat memaksimalkan bonus yang mereka terima. Penelitian (Suryatiningsih \& Siregar, 2008) juga menunjukkan skema bonus direksi BUMN memberikan insentif kepada direksi untuk melakukan manajemen laba melalui discretionary accruals yang meningkatkan laba guna memaksimalkan bonus yang diterimanya. Hasil pengujiannya menunjukkan bahwa secara umum variabel-variabel perhitungan skema bonus yaitu laba dibagi, indeks pencapaian laba terhadap tahun lalu, dan indeks pencapaian anggaran laba signifikan mempengaruhi besaran discretionary accruals. Variabel-variabel perhitungan skema bonus tersebut juga terbukti berhubungan positif dengan discretionary accruals positif.

\section{Kepemilikan Institusional dan Kompensasi Bonus berpengaruh terhadap Manajemen Laba}

Menurut Pujiati dan Arfan (2013) Menguji pengaruh kepemilikan manajerial, kepemilikan institusional, dan kompensasi bonus terhadap manajemen laba pada perusahaan manufaktur di BEI tahun 20062010. Berdasarkan hasil pengujian hipotesis diperoleh kesimpulan sebagai berikut: Kepemilikan manajerial, kepemilikan institusional, dan kompensasi bonus secara bersama-sama berpengaruh terhadap manajemen laba, Kepemilikan manajerial berpengaruh negatif terhadap manajemen laba, Kepemilikan institusional berpengaruh negatif terhadap manajemen laba dan Kompensasi bonus berpengaruh negatif terhadap manajemen laba pada perusahaan manufaktur di BEI. 


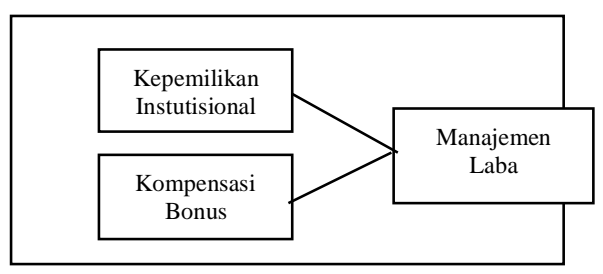

Gambar 1

Model Penelitian

\section{METODE PENELITIAN}

Penelitian ini bertujuan untuk menguji pengaruh variabel independen (Kepemilikan Instutisional dan kompensasi bonus) terhadap variabel dependen (manajemen laba) melalui pengujian hipotesis. Jenis penelitian yang digunakan dalam penelitian ini adalah penelitian verifikatif. Tipe hubungan antar variabel adalah hubungan kausal, yaitu tipe hubungan yang menjelaskan pengaruh variabel independent terhadap variabel dependen atau tipe hubungan yang menjelaskan hubungan sebab akibat antar variabel (Sekaran \& Bougie, 2009:110). Unit analisis dalam penelitian ini adalah tingkat Jasa, yaitu perusahaan Asuransi di Bursa Efek Indonesia yang melakukan manajemen laba dengan cara menaikkan laba (income-increasing discretionary accruals). Horizon waktu yang digunakan adalah unbalanced panel data (setiap unit cross-sectional memiliki jumlah observasi yang tidak selalu sama untuk setiap waktu/periode)

\section{Populasi dan Sampel}

Populasi dalam penelitian ini adalah perusahaan asuransi yang terdaftar di BEI periode tahun 2017 - 2019. Berdasarkan ketentuan tersebut, jumlah populasi penelitian ini adalah 44 pengamatan perusahaan, yaitu: tahun 2017 berjumlah 14 perusahaan, tahun 2018 berjumlah 15 perusahaan, dan tahun 2019 berjumlah 15 perusahaan. Berhubung elemen populasi penelitian ini jumlahnya tidak banyak (hanya 44 pengamatan), maka seluruh elemen populasi diteliti. Dengan kata lain, metode penelitian yang digunakan adalah metode sensus.

\section{Operasionalisasi Variabel \\ Manajemen Laba}

(Scott \& Scott, 2015) memberikan definisi manajemen laba sebagai berikut: "earnings management is the choice by a manager of accounting policies so as to achieve some specific objectives". Manajemen laba adalah potensi penggunaan manajemen akrual dengan tujuan memperoleh keuntungan pribadi. Untuk mengukur tingkat manajemen laba digunakan discretionary accruals dan dihitung dengan The Modified Jones Model 1991 sebagaimana digunakan oleh model yang paling baik dalam mendeteksi manajemen laba dibandingkan dengan model lain (Dechow, Sloan, \& Sweeney, 1995). Alasan pemilihan model Jones yang dimodifikasi ini karena model ini dianggap sebagai serta memberikan hasil yang paling kuat (Dechow et al., 1995).

Total akrual diperoleh dari selisih laba bersih dan arus kas dari operasi. Total akrual sebuah perusahaan dipisahkan menjadi non discretionary accruals (tingkat akrual normal) dan discretionary accruals (tingkat akrual tidak normal), dapat di rumuskan sebagai berikut:

TA = Laba bersih - Arus kas dari operasi

$\mathrm{TA}=$ akrual normal (NDA) + akrual tidak normal (DA)

Akrual yang tidak diharapkan atau akrual tidak normal dianggap sebagai komponen yang tidak dapat dijelaskan (residual) dari total akrual. Tingkat akrual yang tidak normal ini merupakan tingkat 
akrual hasil rekayasa laba yang dilakukan oleh manajer.

Langkah-langkah dalam menghitung Discretionary accruals adalah sebagai berikut:

$\mathrm{DA}=\mathrm{TA}-\mathrm{NDA}$

$\mathrm{TA}=\mathrm{NDA}+\mathrm{DA}$

Total Accural (TCA)

$T A C=N I_{i t}-C F O_{i t}$

Mengestimasi Total Accural (TAC) dengan Ordinary Least Square (OLS) untuk mendapatkan regresi

$$
\begin{gathered}
\frac{T A_{i t}}{A_{i t-1}}=\beta_{1} \\
\left(\frac{1}{A_{i t-1}}\right)+\beta_{2}\left(\frac{\Delta R e v_{i t}}{A_{i t-1}}\right) \\
+\beta_{3}\left(\frac{P P E_{i t}}{A_{i t-1}}\right)+\varepsilon
\end{gathered}
$$

Menghitung Nondiscretionary Accurals (NDA)

$$
\begin{aligned}
N D A_{i t}=\beta_{1}( & \left.\frac{1}{A_{i t-1}}\right) \\
& +\beta_{2}\left(\frac{\Delta R e v_{i t}}{A_{i t-1}}-\frac{\Delta R e c_{i t}}{A_{i t-1}}\right) \\
& +\beta_{3}\left(\frac{P P E_{i t}}{A_{i t-1}}\right)
\end{aligned}
$$

Menghitung Discretionary Accurals (DA) sebagai ukuran dari manajemen laba

$$
D A_{i t}=\left(\frac{T A_{i t}}{A_{i t-1}}\right)+N D A_{i t}
$$

$\mathrm{DA}=$ Estimasi discretionary accruals perusahaan i pada periode ke $\mathrm{t}$

$\mathrm{TA}=$ Total accruals perusahaan $\mathrm{i}$ pada periode ke $\mathrm{t}$

NDA $=$ Estimasi non-discretionary accruals perusahaan i pada periode ke $\mathrm{t}$

Tait $=$ Total accruals perusahaan i pada periode ke $\mathrm{t}$
Ait-1 = Total assets perusahaan i pada periode ke $\mathrm{t}-1$

$\triangle \mathrm{REV}=$ Perubahan penjualan bersih perusahaan i dari tahun $\mathrm{t}-1$ ke tahun $\mathrm{t}$ $\triangle \mathrm{REC}=$ Perubahan piutang bersih perusahaan i dari tahun $\mathrm{t}-1$ ke tahun $\mathrm{t}$ PPEit = Aktiva tetap (gross property, plant, and equipment) perusahaan i pada periode ke $\mathrm{t}$

\section{Kepemilikan Institusional}

Kepemilikan institusional adalah proporsi kepemilikan saham yang dimiliki oleh pihak institusional seperti perusahaan, lembaga keuangan, perusahaan investasi dan koperasi. Pengukuran untuk menghitung kepemilikan institusional adalah persentase saham yang dimiliki oleh lembaga atau institusi yang dapat dirumuskan sebagai berikut (Koh, 2003):

\section{KI \\ $=\frac{\text { Jumlah saham Institusi }}{\text { Total Saham Perusahaan }} \times 100 \%$}

\section{Kompensasi Bonus}

Program kompensasi manajemen adalah kebijakan dan prosedur untuk memberikan kompensasi bagi manajer, mencakup pemberian bonus yang didasarkan pada pencapaian tujuan-tujuan kinerja untuk suatu periode (Blocher, Chen, Cokins, \& Lin, 2007). Variabel ini menggunakan variabel dummy, yaitu dengan menggunakan skala 1 apabila terdapat pemberian kompensasi bonus kepada manajemen dan skala 0 apabila tidak terdapat pemberian kompensasi bonus kepada manajemen.

\section{Metode Analisis}

Untuk menguji dan menganalisis pengaruh kepemilikan manajerial, kepemilikan institusional dan kompensasi 
bonus terhadap manajemen laba pada perusahaan manufaktur di Bursa Efek Indonesia digunakan model analisis regresi linear berganda (multiple regresion model). Model tersebut diformulasikan sebagai berikut:

$$
\begin{aligned}
& \mathrm{Y}_{\text {it }}=\alpha+\beta 1 \mathrm{X}_{1 \mathrm{it}}+\beta 2 \mathrm{X}_{2 \mathrm{it}}+\beta 3+ \\
& \varepsilon_{\text {it }}
\end{aligned}
$$

Keterangan

Y it = Manajemen laba perusahaan $\mathrm{i}$

tahun $\mathrm{t}$

$\alpha=$ Konstanta

$\beta_{1}, \beta_{2}, \beta_{3}=$ Koefisien regresi

$\mathrm{X}_{1}$ it $=$ Kepemilikan Institusional perusahaan i tahun $\mathrm{t}$

$\mathrm{X}_{2}$ it $=$ Kompensasi bonus perusahaan $\mathrm{i}$ tahun $\mathrm{t}$

$\varepsilon$ it $=$ Error term (variabel yang tidak dimasukkan dalam model penelitian ini)

\section{HASIL DAN PEMBAHASAN Deskripsi Data Penelitian}

Penelitian ini adalah penelitian empiris pada perusahaan asuransi yang terdaftar di BEI mengenai Kepemilikan Institusional dan kompensasi bonus serta pengaruhnya terhadap manajemen laba. Penelitian ini menggunakan data sekunder yang diperoleh langsung dari laporan keuangan tahunan perusahaan asuransi yang diterbitkan oleh BEI. Deskripsi data penelitian dapat dilihat pada Tabel 1 .

Tabel 1

\begin{tabular}{|c|c|c|c|c|}
\hline \multicolumn{5}{|c|}{ Descriptive Statistics } \\
\hline & $\begin{array}{cc}\mathbf{N} & \text { Mini } \\
\mathbf{m u} & \mathbf{m}\end{array}$ & $\begin{array}{c}\text { Max } \\
\text { imu } \\
\text { m }\end{array}$ & $\begin{array}{c}\text { Mea } \\
\text { n }\end{array}$ & $\begin{array}{l}\text { Std. } \\
\text { Dev }\end{array}$ \\
\hline $\begin{array}{l}\text { Kepemilikan } \\
\text { Instutional }\end{array}$ & $44^{, 223}$ & 1,000 & 6937 & ,23406 \\
\hline $\begin{array}{l}\text { Kompensasi } \\
\text { Bonus }\end{array}$ & $44^{, 000}$ & 1,000 & ,6136 & ,49254 \\
\hline
\end{tabular}

Deskripsi Data Penelitian

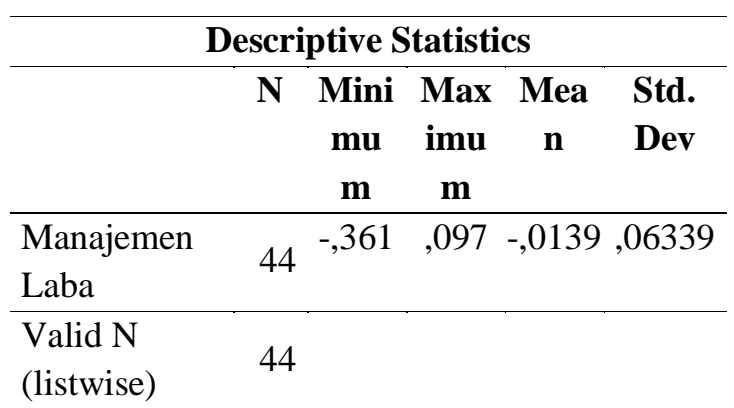

Berdasarkan Tabel 1 dapat dilihat nilai terendah, tertinggi dan rata-rata dari variabel yang diteliti dengan 44 pengamatan perusahaan selama tahun 2017-2019. Variabel dependen manajemen laba yang diproksi dengan discretionary accruals diperoleh nilai terendah sebesar -0,361, yang bermakna bahwa manajemen laba dilakukan sebesar $-36,1 \%$ dari total aktiva perusahaan. Nilai tertinggi diperoleh sebesar 0,097, artinya manajemen laba dilakukan dengan sebesar $9,7 \%$ dari total aktiva perusahaan. Nilai rata-rata tingkat manajemen laba sebesar -0,139 artinya manajemen laba rata-rata dilakukan sebesar $-1,39 \%$ dari total aktiva perusahaan.

Variabel independen pertama yaitu Kepemilikan Institusional dengan nilai terendah sebesar 0,223, artinya jumlah kepemilikan saham perusahaan yang dimiliki oleh terendah sebesar $22,3 \%$ dari jumlah saham yang beredar. Nilai tertinggi diperoleh sebesar 1, artinya jumlah kepemilikan saham perusahaan yang dimiliki oleh pihak perusahaan tertinggi sebesar $100 \%$ dari jumlah saham yang beredar. Nilai rata-rata kepemilikan manajerial sebesar 0,693, artinya jumlah kepemilikan saham yang dimiliki oleh pihak manajerial rata-rata sebesar 69,3\% dari jumlah saham yang beredar. Deskripsi data dari variabel independen kedua dapat dilihat pada Tabel 2. 
Tabel 2

Deskripsi Data Variabel Kompensasi Bonus

\section{Percen Valid}

Frequency $t$

Percent Cumulati

ve

\begin{tabular}{cccccc} 
& & & & \multicolumn{2}{c}{$\begin{array}{l}\text { ve } \\
\text { Percent }\end{array}$} \\
\hline Valid & 0 & 17 & 38,6 & 38,6 & 61,4 \\
\hline 1 & 27 & 61,4 & 61,4 & 100.0 \\
\hline $\begin{array}{l}\mathrm{T} \\
\text { ot } \\
\text { al }\end{array}$ & 44 & 100.0 & 100.0 & \\
\hline
\end{tabular}

Sumber: Data sekunder, 2021 (diolah)

Berdasarkan Tabel 2 varibel independen kedua yaitu kompensasi bonus diukur dengan menggunakan variabel dummy. Nilai 1 menunjukkan terdapat 27 pengamatan perusahaan atau $61,4 \%$ dari total pengamatan perusahaan yang memberikan kompensasi bonus kepada pihak manajemennya, sedangkan nilai 0 menunjukkan sebanyak 17 pengamatan perusahaan atau $38,6 \%$ dari total pengamatan perusahaan yang tidak memberikan kompensasi bonus kepada pihak manajemennya.

\section{Hasil Pengujian Hipotesis}

Berdasarkan hasil perhitungan dengan menggunakan bantuan program SPSS (Statistical Product and Service Solutions) versi 20.0, dengan menggunakan analisis regresi linear berganda diperoleh Kepemilikan Instutisional dan kompensasi bonus serta pengaruhnya terhadap manajemen laba pada perusahaan asuransi di Bursa Efek Indonesia tahun 2015-2090 seperti yang terlihat pada Tabel 3 .

\section{Tabel 3}

Hasil Regresi Pengaruh Variabel Independen terhadap Variabel Dependen

Persamaan regresi linear berganda

$\mathrm{Y}=0.052-0.088 \mathrm{X}_{1}-0.007 \mathrm{X}_{2}+\varepsilon$

\begin{tabular}{lll} 
Konstanta (a) & B & Standar \\
\hline
\end{tabular}

\begin{tabular}{lrr}
\hline Kepemilikan & & Error \\
\cline { 2 - 3 } Instutisional & 0.052 & 0.030 \\
Kompensasi Bonus & -0.088 & 0.040 \\
& -0.007 & 0.019 \\
\hline Koefisien korelasi & & \\
$(\mathrm{R})=0.341^{\mathrm{a}}$ & & \\
Koefisien & & \\
determinasi & & \\
$\left(\mathrm{R}^{2}\right)=0.116$ & & \\
Adjusted $\left(\mathrm{R}^{2}\right)=$ & & \\
0.0732 & & \\
\hline
\end{tabular}

Berdasarkan Tabel 4, diperoleh persamaan regresi berganda sebagai berikut:

$$
\mathrm{Y}=0.052-0.088 \mathrm{X}_{1}-0.007 \mathrm{X}_{2}+\varepsilon
$$

Nilai konstanta yaitu 0.052, angka ini menunjukkan bahwa apabila faktor-faktor Kepemikikan Instutisional $\left(\mathrm{X}_{1}\right)$, kompensasi bonus $\left(\mathrm{X}_{2}\right)$, dianggap konstan, maka besarnya manajemen laba pada perusahaan asuransi yang terdaftar di BEI adalah sebesar 0.052 .

\section{Hasil Pengujian Secara Parsial}

Berdasarkan Tabel 3 tersebut dapat diketahui bahwa:

a. Nilai koefisien regresi pengaruh Kepemilikan Institusional $\left(\mathrm{X}_{1}\right)$ terhadap manajemen laba $\mathrm{Y}$ adalah sebesar 0.088. Hasil penelitian ini menolak $\mathrm{H}_{0}$ (hipotesis nol) dan menerima $\mathrm{H}_{\mathrm{a}}$ (hipotesis alternatif), dapat dikatakan bahwa Kepemilikan Institusional saham berpengaruh negatif terhadap manajemen laba pada perusahaan asuransi yang terdaftar di BEI. Nilai koefisien regresi kepemilikan Institusional sebesar -0.088 menunjukkan bahwa setiap adanya kenaikan kepemilikan Institusional sebesar $1 \%$ dari jumlah saham yang beredar akan mengakibatkan penurunan terhadap manajemen laba sebesar 
$0,088 \%$ dari total aktiva, dan kompensasi bonus $\left(\mathrm{X}_{2}\right)$ adalah konstan.

b. Nilai koefisien regresi pengaruh kompensasi bonus (X2) terhadap manajemen laba (Y) adalah sebesar 0.007. Hasil penelitian ini menerima $\mathrm{H}_{0}$ (hipotesis nol) dan menolak $\mathrm{H}_{\mathrm{a}}$ (hipotesis alternatif), dapat dikatakan bahwa kompensasi bonus berpengaruh negatif terhadap manajemen laba pada perusahaan asuransi yang terdaftar di BEI. Nilai koefisien regresi sebesar 0.007 menunjukkan bahwa setiap adanya kompensasi bonus akan mengakibatkan penurunan terhadap manajemen laba sebesar $0,001 \%$ dari total aktiva perusahaan, dan kepemilikan dengan asumsi variabel Kepemilikan Institusional $\left(\mathrm{X}_{1}\right)$ adalah konstan. Sebaliknya tanpa kompensasi bonus manajemen laba tetap konstan dilakukan sebesar $0,052 \%$ dari total aktiva perusahaan.

\section{Pembahasan}

\section{Pengaruh Kepemilikan Institusional terhadap Manajemen Laba}

Berdasarkan hasil uji hipotesis, Kepemilikan Institusional perusahaan berpengaruh negatif terhadap manajemen laba yang ditandai dengan nilai koefisien regresi sebesar -0.088. Pengaruh negatif tersebut bermakna bahwa semakin besar persentase kepemilikan saham perusahaan semakin rendah tingkat manajemen laba yang dilakukan oleh manajer perusahaan Asuransi, sebaliknya semakin kecil persentase kepemilikan saham perusahaan semakin tinggi tingkat manajemen laba yang dilakukan oleh manajer perusahaan asuransi.

Pengaruh negatif ini bisa terjadi karena pihak institusional perusahaan memiliki sebagian dari saham perusahaan, sehingga kecenderungan perusahaan untuk mengatur laba akuntansi menjadi menurun. Dengan adanya kepemilikan saham yang dimiliki oleh perusahaan maka perusahaan akan bertindak sama dengan kepentingan pemegang saham sehingga dapat memperkecil perilaku oportunis perusahaan.

\section{Pengaruh Kompensasi Bonus terhadap Manajemen Laba}

Berdasarkan hasil pengujian hipotesis, kompensasi bonus berpengaruh negatif terhadap manajemen laba yang ditandai dengan nilai koefisien regresi sebesar 0.007. Pengaruh negatif tersebut bermakna bahwa semakin besar kompensasi bonus yang diberikan kepada manajemen semakin rendah tingkat manajemen laba yang dilakukan oleh perusahaan asuransi, sebaliknya semakin kecil kompensasi bonus yang diberikan kepada manajemen semakin tinggi tingkat manajemen laba yang dilakukan oleh perusahaan asuransi. Jadi apabila perusahaan memberikan kompensasi bonus kepada manajemen yang besar, maka semakin rendah praktik manajemen laba yang akan dilakukan perusahaan.

Pengaruh negatif kompensasi bonus terhadap manajemen laba menunjukkan bahwa hasil penelitian ini tidak konsisten dengan bonus plan hypothesis. Hasil penelitian ini juga tidak konsisten dengan hasil penelitian (Palestin, 2009) yang menemukan bahwa kompensasi bonus berpengaruh yang signifikan terhadap manajemen laba.

Pengaruh negatif ini dapat dijelaskan melalui agency teory (Jensen \& Meckling, 1976). Berdasarkan agency teory pemberian kompensasi atau insentif yang besar berarti semakin luas kebijakan manajer untuk mempengaruhi laba pada saat melaporkan kondisi perusahaan. Ketika 
pemberian kompensasi atau insentif tinggi, pemegang saham berupaya melakukan kontrol yang lebih ketat terhadap kebijakan manajer perusahaan. Hal ini dilakukan oleh pemegang saham dalam upaya untuk mengurangi perilaku perusahaan melakukan manajemen laba. Berdasarkan deskripsi data penelitian juga menunjukkan bahwa dari 44 pengamatan perusahaan yang dijadikan populasi sasaran terdapat 27 pengamatan perusahaan yang memberikan kompensasi bonus kepada pihak karyawannya.

\section{Pengaruh Kepemilikan Institusional dan} Kompensasi Bonus terhadap Manajemen

\section{Laba}

Berdasarkan hasil pengujian hipotesis, kepemilikan Institusional dan kompensasi bonus berpengaruh terhadap manajemen laba.

Koefisien korelasi $(\mathrm{R})=0.341$ yang menunjukkan bahwa derajat hubungan (korelasi) antara variabel dependen dan variabel independen sebesar $34.1 \%$. Artinya manajemen laba mempunyai hubungan yang lemah dengan kepemilikan Institusional $\left(\mathrm{X}_{1}\right)$ dan Kompensasi Bonus $\left(\mathrm{X}_{2}\right)$, karena diperoleh nilai koefisien korelasi diantara 0.20-0.40 dengan menggunakan klasifikasi Guilford (1956) dalam Arfan (2008). Untuk mengetahui besarnya pengaruh variabel lain yang tidak dimasukkan dalam ini model penelitian ini $(\varepsilon)$ dihitung dengan cara yang digunakan oleh Loather dan McTavish (1993) dalam Arfan (2008) dengan rumus sebagai berikut:

$$
\varepsilon=1-\mathrm{R}^{2} \text { Koefisien determinasi }\left(\mathrm{R}^{2}\right)
$$

$=0.116$, artinya sebesar $11,6 \%$ perubahanperubahan yang terjadi pada manajemen laba (Y) dapat dijelaskan oleh perubahanperubahan yang terjadi pada kepemilikan Institusional $\left(\mathrm{X}_{1}\right)$, dan kompensasi bonus
$\left(\mathrm{X}_{2}\right)$, sedangkan selebihnya sebesar $88.4 \%$ dijelaskan oleh faktor-faktor variabel lain yang tidak dimasukkan dalam model penelitian ini. Penelitian mengenai manajemen laba terus berkembang dan ditemukan banyak variabel yang mempengaruhinya yang tidak turut diuji dalam penelitian.

\section{KESIMPULAN}

Penelitian ini dilakukan untuk menguji pengaruh kepemilikan manajerial, kepemilikan institusional, dan kompensasi bonus terhadap manajemen laba pada perusahaan asuransi di BEI tahun 2015-2019.

Berdasarkan hasil pengujian hipotesis diperoleh kesimpulan sebagai berikut:

1. Kepemilikan Institusional berpengaruh negatif terhadap manajemen laba pada perusahaan asuransi di BEI.

2. Kompensasi bonus berpengaruh negatif terhadap manajemen laba pada perusahaan asuransi di BEI.

3. Kepemilikan Institusional dan kompensasi bonus berpengaruh terhadap manajemen laba pada perusahaan Asuransi di BEI.

\section{DAFTAR PUSTAKA}

Bernandhi, Riza, \& Muid, Abdul. (2013). Pengaruh Kepemilikan Manajerial, Kepemilikan Institusional, Kebijakan Dividen, Leverage Dan Ukuran Perusahaan Terhadap Nilai Perusahaan. Fakultas Ekonomika dan Bisnis.

Blocher, E. J., Chen, K. H., Cokins, G., \& Lin, T. W. (2007). Cost Management, Manajemen Biaya. 
diterjemahkan oleh Tim Penerjemah Penerbit Salemba. Edisi Ketiga. Buku Kedua. Salemba Empat. Jakarta.

Dechow, Patricia M., Sloan, Richard G., \& Sweeney, Amy P. (1995). Detecting earnings management. Accounting Review, 193-225.

Fama, Eugene F. (1978). The effects of a firm's investment and financing decisions on the welfare of its security holders. The American Economic Review, 68(3), 272-284.

Ghozali, Imam. (2005). Aplikasi Analisis Multivariate dengan Program SPSS. Semarang: Badan Penerbit Universitas Diponegoro.

Jensen, Michael C., \& Meckling, William H. (1976). Theory of the firm: Managerial behavior, agency costs and ownership structure. Journal of Financial Economics, 3(4), 305-360.

Koh, Ping Sheng. (2003). On the association between institutional ownership and aggressive corporate earnings management in Australia. The British Accounting Review, 35(2), 105-128.

Lin, Yongjia Rebecca, \& Fu, Xiaoqing Maggie. (2017). Does institutional ownership influence firm performance? Evidence from China. International Review of Economics $\&$ Finance, 49, 17-57.

Palestin, Halima Shatila. (2009). Analisis pengaruh struktur kepemilikan, praktik Corporate governance dan kompensasi bonus Terhadap Manajemen laba (studi empiris pada di PT Bursa efek indonesia). Diponegoro University.

Scott, William R., \& Scott, William R. (2015). Financial accounting theory. Pearson Canada Inc.

Sulistyanto, Sri. (2008). Manajemen Laba (Teori \& Model Empiris). Grasindo.

Suryatiningsih, Neneng, \& Siregar, Sylvia Veronica. (2008). Pengaruh skema bonus direksi terhadap aktivitas manajemen laba (studi empiris pada badan usaha milik negara) periode tahun 2003-2006. Jurnal Dan Prosiding SNA-Simposium Nasional Akuntansi, 11. 